\title{
Osmanlı Ülkesinde Son Safevî Şehzâdeleri: Sam Mirzâlar
}

\section{The Last Safavid Princes in the Ottoman Territories: the Sam Mirzas}

\author{
Ömer İşbilir* (1)
}

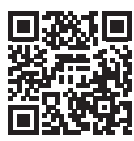

*Prof. Dr., Mimar Sinan Güzel Sanatlar Üniversitesi, Fen-Edebiyat Fakültesi, Tarih Bölümü,

İstanbul, Türkiye

ORCID: Ö.I. 0000-0002-5406-0856

Sorumlu yazar/Corresponding author: Ömer İşbilir,

Mimar Sinan Güzel Sanatlar Üniversitesi,

Fen-Edebiyat Fakültesi, Tarih Bölümü,

Istanbul, Türkiye

E-posta/E-mail: omarisbilir@yahoo.com

Başvuru/Submitted: 23.06 .2020 Revizyon Talebi/Revision Requested: 26.06.2020

Son Revizyon/Last Revision Received: 08.07.2020

Kabul/Accepted: 11.07 .2020

\section{Atıf/Citation:}

Isbilir, Omer. "Osmanlı Ülkesinde Son Safevî Şehzâdeleri: Sam Mirzâlar." Tarih Dergisi - Turkish Journal of History, 71 (2020): 239-254. https://doi.org/10.26650/TurkJHist.2020.014

\section{öz}

On sekizinci yüzyıl başlarında İran'da meydana gelen karışıklıklardan sonra Safevî hanedânı sona ermiş ve bunun neticesi olarak hanedân mensubu bazı şehzâdeler aralıklarla Osmanlı Devleti'ne sığınmışlardır. Osmanlı Devleti, başlangıçta bunlardan siyasî olarak istifade etmek istemiş ve bu maksadla ilk iltica eden Safî Mizâ'yı şah ilan ederek İran tahtına iclâs etmeyi hedeflemişti. Ancak bu arzusunu gerçekleştirme fırsatı bulamamıştır. Osmanlı Devleti, Safí Mirzâ'dan umduğunu bulamamış olmasına rağmen, daha sonra yine Şah Hüseyin'in ve Tahmasb'ın oğlu oldukları iddiasıyla gelen iki Safevî şehzâdesinin ilticâlarını kabul etmekte tereddüd göstermemiştir. Her ikisinin de adları Sam olan bu şehzâdeleri, önce Sinop'ta, daha sonra Şah Hüseyin'in oğlu olan Sam Mirzâ'yı Limni Adası'nda, Tahmasb'ın oğlu olan Sam Mirzâ'yı ise Sinop'tan sonra kısa süre Rodos Adası'nda ve nihayet Gelibolu'da iskân etmiştir. Safevî şehzâdelerinin yanlarında kalabalık aile efradı ve yine hatırı sayılır miktarda maiyet halkı vardır. İkamet ettikleri her yerde, günlük geçimlerini temin etmek maksadıyla kendilerine gümrükten veya cizye kaleminden tahsîsâtlar verilmiş, sıkıntı çekmemelerine intimam edilmiştir. Bununla beraber şehzâdelerin hareketleri sürekli gözetim altında tutulmuş, izinsiz olarak iskân edildikleri yerden bir başka yere gitmelerine asla müsaade olunmamıştır. Şah Hüseyin'in oğlu Sam Mirzâ Limni Adası'nda, Tahmasb'ın oğlu ise Gelibolu'da vefat etmiş ve her ikisi de vefat ettikleri yerde defnedilmişlerdir. Kendilerine tayin edilmiş olan tahsîsât, vefatlarından sonra eşlerine, çocuklarına ve maiyet halkına taksim olunmuş, aile efradından vefat eden olduğunda da maaşı hazineye alınmayıp yine ailenin sağ kalan ferdleri arasında paylaştırılmıştır. Her iki Sam Mirza'nın çocukları ve ahfâdı, babalarının vefatından sonra İran'a dönmeyi tercih etmemişler ve Osmanlı topraklarında hayatlarını idame ettirmişlerdir. Bunlarla alakalı belgelerden Osmanlı Devleti'nin son anına kadar bu topraklarda kaldıkları anlaşılmaktadır.

Anahtar sözcükler: Sam Mirzâ, Safî Mirzâ, Safevî şehzâdeleri, İran, Nadir Şah

\section{ABSTRACT}

After the turmoil in Iran at the beginning of the eighteenth century, the Safavid dynasty ended and as a result there were certain intervals when some members of the dynasty took refuge in the Ottoman State. The Ottoman Empire initially wanted to take advantage of them politically and, with this aim in mind, an attempt was made to set Safî Mirzâ, the first asylum seeker, on a throne declaring him to be a shah. However, the opportunity to fulfill this 
desire was not found. Although the Ottoman State could not find what it hoped for Safi Mirzâ, it did not hesitate to accept the asylum of the two Safavid princes, who later came to claim that they were the sons of Shah Hüseyin and Tahmasb.

These princes, both of whom were called Sam, were first settled in Sinop. Later Sam Mirza, the son of Shah Huseyin, moved to Limnos Island, and Sam Mirza, the son of Tahmasb, settled on Rodos Island shortly after leaving Sinop, and he finally moved to Gallipoli. The Safavid princes had many family members and a considerable amount of employees. Wherever they resided, they were given customs or 'jizya' to ensure their daily livelihoods.

However, the movements of the princes were kept under constant surveillance, and they were never allowed to move from one place to another without permission. Sam Mirzâ, Shah Huseyin's son, died on Limnos Island, and Tahmasb's son died in Gallipoli, and both were buried where they died. After their death, the allocation assigned to them was allocated to their spouses, children and the people of the family, and when the family passed away, the salary was not given to the treasury but shared among the surviving members of the family.

Neither the children nor the descendants of the two Sam Mirzas chose to return to Iran after their father's death, and they continued their lives in Ottoman lands. It is understood from related documents that they remained in these lands until the collapse of the Ottoman State.

Keywords: Sam Mirzâ, Safî Mirzâ, Safavid Princes, Iran, Nadir Shah

\section{Giriş}

18. yüzyıl başlarında İran Safevî Devleti’nde birbiri ardına meydana gelen siyasî karışıklıklar ve iktidar mücadeleleri Safevî Hanedânı'nın sonunu getirmiş ve hanedân mensubu olan bazı kişilerin siyasî ilticâlarına müncer olmuştur. Genel hatlarıyla bu kargaşa dönemini şu şekilde özetleyebiliriz: Abdalî Afganlarının baskısı neticesinde, başkentini Isfahan'dan Kazvin'e taşıyan Şah Hüseyin, Gılzay Afganların reisi olan Mahmud Han'ın desteğiyle Abdalîleri itâat altına aldı. Ancak bu sırada gücünü ve nüfûzunu artıran Mahmud Han, Şah'a başkaldırarak 8 Mart 1722'de Şah'ın birliklerini bozguna uğrattı ve Isfahan'da Şah'1 kuşattı. Altı ay süren bu çetin kuşatma sonunda açlık, sefalet ve ölümlerin artmasıyla Ekim 1722'de Şah Hüseyin teslim oldu ve tahttan feragat etti. Şubat 1725 tarihinde Şah Hüseyin'in oğlu Safî Mirza'nın Isfahan'dan firarı üzerine Mahmud Han Afganî, Şah Hüseyin ve iki küçük şehzadesi dışında bütün hanedan üyelerinin öldürülmesini emretti. Bunun neticesinde on sekiz şehzade katledilmiştir. Nisan 1725 yılında Gılzay Afganlardan Eşref, Mahmud Han’ı bertaraf ederek şah oldu. Daha sonra Osmanlı Devleti'nin eski şahı tekrar tahta çıkarmak için İran üzerine yürümesi üzerine korkuya kapılarak Şah Hüseyin’i öldürttü.

Diğer taraftan Şah Hüseyin'in tahttan çekilmesinden sonra, oğlu Abbas Mirza, Afşar Türklerinden Nadir Han'ın da desteğini kazanarak 10 Kasım 1722'de II. Tahmasb olarak kendini şah ilan etti. Nitekim Nadir, Eşref üzerine yürüyerek onu bozguna uğrattı ve Kasım 1729'da Isfahan'a girerek Tahmasb'1 buraya davet etti. Ancak Nadir'in Tahmasb'a olan bu desteği uzun sürmedi. 10 Ocak 1732'de Osmanlı Devleti ile İran arasında yapılan anlaşmadan duyduğu memnuniyetsizlik sonucu Tahmasb'ı tahttan indirerek, Tahmasb'ın henüz birkaç aylık olan oğlu Abbas'1, III. Abbas namıyla İran tahtına çıkardı. Ancak "Vekîlü’d-devle" unvanıyla hâkimiyeti tamamen kendi eline aldı. Nihâyet 8 Mart 1736'da yirmi bin kişinin 
katıldığı bir kurultay sonucunda Nadir Şah unvanıyla İran hükümdarı ilan edildi. Böylece İran'da Safevî Hânedânı devri tamamen sona ermiş oluyordu'.

Şah Hüseyin'in tahttan ferâgatıyla başlayan ve Nadir'in İran tahtına oturmasıyla devam eden süreç ve sonrası, Safevî Hanedânı'na mensup olduğunu iddia eden birçok kişinin ortaya çıkmasına sahne olmuştur. Bunlardan üç tanesi kısa aralıklarla Osmanlı Devleti’ne sığınmışlardır. Osmanlı Devleti'nin, kurulduğu asırdan beri, iltica sebeplerine bakmaksızın -bazen devletlerarası krizlere sebep olsa bile- kendisine sığınan hiç kimseyi geri çevirmediği ve bunları, kendi rızalarıyla memleketlerine dönünceye kadar her türlü ihtiyaçlarını karşılayarak himaye ettiği bilinmektedir. Aynı şekilde bu Safevî şehzadelerine de sahip çıkmış ve onları topraklarında barındırmıştır. İbrahim Güler'in, on sekizinci yüzyılda Sinop'ta ikamet eden Safevî şehzâdelerini² ve Eyal Ginio'nun Safî Mirzâ'nın Selanik’teki ikametini ${ }^{3}$ konu alan makaleleri istisna edilirse bu şehzâdeler hakkında bugüne kadar fazla araştırma yapılmamıştır. Zikredilen makalelerden birincisinde, Safî Mirzâ ile bir müddet Sinop’ta ikamet eden iki Sam Mirzâ birbirine karıştırılmış, hatta farklı tarihlerde Osmanlı Devleti'ne ilticâ eden iki farklı Sam Mirzâ aynı kişilermiş gibi sunulmuştur. İkinci makale ise, Safî Mirzâ'nın Selanik’teki ikameti ile sınırlı kalmıştır.

Kısa bir süre önce bu üç şehzâdeden Şah Hüseyin'in oğlu olan Safî Mirzâ'nın Osmanlı Ülkesi'nin değişik yerlerindeki inişli-çıkışlı hayatı ana hatlarıyla tarafımızdan ele alınmıştı ${ }^{4}$. Safî Mirzâ hakkında Osmanlı kroniklerinde yetersiz de olsa malumat bulunmakla beraber maalesef daha sonra gelen her iki Sam Mirzâ hakkında kırıntı kabilinden dahi bilgiye rastlanmamıştır. Bunlar hakkındaki bütün kayıtlar, Osmanlı Arşivi'nin değişik tasniflerinde yer alan defter ve dosyalardan elde edilmiştir. Şimdilik ulaşabildiğimiz arşiv belgelerinin vermiş olduğu kısıtlı bilgilerle Limni Adası'nda ve Gelibolu'da vefat eden ve her ikisinin de ismi Sam olan bu mirzâların Osmanlı topraklarındaki serüvenleri ana hatlarıyla ele alınmaya çalışılacaktır 5 .

1 Ayrıntılar için bk. V. Minorsky, “Nadir”, İA, c. IX, İstanbul 1988, s. 21-31; R. M. Sanvory, "Safevî İran' '”, İslam Tarihi Kültürü ve Medeniyeti, c. I, çev. Mehmet Maksudoğlu, İstanbul 1988, s. 426-427; M. Münir Aktepe, "Mahmud I", IA, c. VII, İstanbul 1988, s. 158-165; Azmi Özcan, "Nadir Şah", DIA, c. XXXII, İstanbul 2006, s. 276-277; Tufan Gündüz, "Safevîler", DIA, c. XXXV, İstanbul 2008, s. 451-457; Ahmet Taşağıl, "Hüseyin Mirza", DİA, c. XIX, İstanbul 1999, s. 1-2; Gene R. Garthwaite, Iran Tarihi, Pers Imparatorluğu'ndan Günümüze, çev. Fethi Aytuna, İstanbul 2011, s. 167-168.

2 İbrahim Güler, “XVIII. Yüzyılda Sinop’ta İran Şehzâdeleri”, Prof. Dr. Hakkı Dursun Yıldız Armağanı, İstanbul 1995 , s. 259-266.

3 Eyal Ginio, "Beyaz Kule Şehrinde Bir Safevî Prensi: Selanik’teki Beyzâde (1731-1734)”, çev. Özgür ÇınarlıÇağdaş Fırat, Türkler, c. XII, Ankara 2001, s. 576-581.

4 Ömer İş̧ilir, "Osmanlı Ülkesi’nde Bir Safevî Şehzâdesi: Safî Mirzâ", Tarihin Peşinde Bir Ömür -Abdülkadir Özcan'a Armağan, İstanbul 2018, s. 543-560.

5 Bu üç Safevî şehzâdesi ve onların torunlarının Osmanlı ülkesindeki hayatları neredeyse Osmanlı Devleti’nin sonuna kadar sürmüştür. Bir üstteki dipnotta görüldüğü üzere Safî Mirzâ daha önce bir makalede tarafımdan incelenmeye çalışılmıştı. Bu çalışmanın konusu ise her iki Sam Mirzâdır. Özellikle Sam Mirzâların yanlarında epeyce kalabalık maiyeti olduğu anlaşılmaktadır. Sam Mirzâların 1327/1909 tarihine kadar takip ettiğim evlad, torun ve etbaları hakkında malzeme toplanmaya devam edilmekte olup başka bir çalışmada incelenecektir. 


\section{Limni Adası'nda Vefat Eden Sam Mirzâ}

Şah Hüseyin'in oğlu olduğu iddiasıyla Osmanlı Devleti'ne sığınan Sam Mirzâ'nın iltica ettiği mekân, Sinop'taki ikametine kadar uğradığı yerler ve tarih hakkında tam bir sarahat bulunmamaktadır. Sam Mirzâ'nın kethudası Rüstem Han-zâde Abdullah Bey, Kırım Hanı Kırım Giray’ın da iltimasıyla sunduğu, kendisine tayin olunan 180 akçe yevmiyesinin Tekfurdağı Gümrüğünden verilmesine dair arz-1 halinde, şehzâdenin, Erzurum ve Kars taraflarına gönderildiğinde, daha sonra 1161/1748 senesinde Tokat'tan Sinop'a intikalinde, İran elçisine terfik edilmek üzere Sinop’tan çıkarıldığında, nihayet maiyeti ile birlikte Limni Adası'nda ikameti emrolunarak buraya geldiklerinde hep yanında bulunduğunu söylemektedir. Buradan anlaşılacağı üzere, Mirzâ Sam'ın, Erzurum, Kars, Tokat, Sinop, Amasya ve sonunda Limni Adası'nda iskân edilmesine karar verilmiştir'.

Sinop Kalesi, İran'dan Osmanlı Devleti'ne sığınan her üç şehzâdenin de bir müddet ikamet ettikleri şehir olarak dikkat çekmektedir. Yukarıda zikredilen belgede, Sam Mirzâ'nın Sinop'a geliş tarihi 1161/1748 olarak verilmektedir. Sam Mirzâ ve yanındaki dokuz kişinin Sinop Kalesi'nde ikamet ettirilmesi hususunda, hükümet merkezi ile Sinop Kadısı ve Sinop Kalesi dizdarı arasında bir dizi yazışma olduğu anlaşılmaktadır. Buna göre, merkezden gelen emir gereğince Sam Mirza ve yanındaki kişilerin eşyaları kendileri huzurunda defter edilerek yine kendilerine mühürletilip güvenli bir yere konulmuştu. Daha sonra Sam Mirzâ'nın İstanbul'a arz-1 hal sunarak zabt edilen eşyalarının geri verilmesini istemesi üzerine söz konusu eşyaların iade edilmesi ve buna dair senedin İstanbul'a gönderilmesi istenmiştir ${ }^{7}$. Bir diğer hükümde ise, aynı hususlara ilaveten, Sam Mirzâ ve dokuz nefer adamlarının Sinop'ta ikametlerine ihtimam edilmesi, maliye tarafından yazılan emir gereği kendilerine günlük tayinât verilmesi, ancak Sinop dışına izinsiz bir adım dahi atmasına müsaade olunmaması bildirilmekteydi ${ }^{8}$. Zikredilen her iki hüküm de evasıt-1 Zilka'de 1160/Kasım 1747 tarihini taşımaktadır. İstanbul ile Sinop arasında emir ve arz-1 hallerin gidip gelme süreleri nazara alındığında Sam Mirzâ'nın Sinop'a geliş tarihi, 1159 sonu veya 1160 başları (Aralık 1746-Şubat 1747) olsa gerektir. Şu halde yukarıda bahsedilen Sam Mirzâ'nın kethüdasının Sinop'a varış tarihi olarak verdiği 1161/1748 tarihi ihtiyatla karşılanmalıdır.

Sam Mirzâ'nın Sinop'ta ikameti 3 yıl kadar sürmüştür. Ancak daha önce Safî Mirzâ ve bundan sonra Tahmasb Şâh'ın oğlu diğer Sam Mirzâ'da olduğu gibi, Sinop ahalîsi ile hüsn-i imtizâcı olmadığına dair arz ve mahzarlar neticesinde Şâh Hüseyin oğlu Sam Mirzâ'nın havass- $\iota$ etbâ 'ından on kişiyle birlikte Limni Adası'na nakledilmesi ve Limni Adası'na vardıktan sonra burada ikamet ettirilip hakkında emir gelmedikçe adanın dışına

BOA, C.HR, nr. 8618 .

Sinop Kadısı ve Sinop Kalesi Dizdarı'na hüküm, BOA, Mühimme, nr. 153, s. 154/591.

Sinop Kadısı'na, Sinop Kalesi Dizdarı'na ve ahalî-i vilayete hüküm, BOA, Mühimme, nr. 153, s. 156/601. 
çıkmasına ve firarına asla müsaade olunmaması emredilmiştir'. Evail-i Rebiülâhır 1163/ Mart 1750 tarihli diğer bir hükümden anlaşıldığına göre, Sam Mirzâ, kendisini Sinop’tan Limni Adası'na götürmekle görevlendirilen mübaşirin İstanbul'dan gelmesini beklemeden İstanbul'a gitmiş ve buradan Limni'ye gönderilmiş, menkûhe ve cevârî makūlesinden on kişi kadar bazı yakınlarının ise Sinop’ta kalması münasebetiyle bunların da bir an evvel Limni'ye ulaştırılarak Sam Mirzâ'ya teslim edilmesi istenmiştir ${ }^{10}$. Artarda gönderilen bu hükümlerde Sam Mirzâ'nın yanında bulunan kişiler on kişi olarak gösterilmiştir. Ancak aşağıda verilen tabloda da görüleceği üzere sadece aile efradının sayısı kendisi hariç üç hanımı, altı erkek ve beş de kız çocuğu olmak üzere on dört kişidirr ${ }^{11}$. Aile efradının Sinop'ta beraberinde mi yoksa sonradan mı Limni Adası'na geldiklerine dair belgelerde bir sarahat da yoktur.

\begin{tabular}{|l|l|l|}
\hline \multicolumn{2}{|c|}{$\begin{array}{c}\text { Tablo 1 } \\
\text { Sam Mirzâ'nın Aile Efradı } \\
\text { (Limni'de Vefat Eden) }\end{array}$} \\
\hline Zevceleri & Oğulları & Kuzları \\
\hline Meryem Hatun & Ali Mirzâ & Hatice Hanım \\
\hline Bebri? Hatun & Mehmed Mirzâ & Fatıma Hanım \\
\hline Ümmükülsüm Hatun & Abbas Mirzâ & Zeyneb Hanım \\
\hline & Süleyman Mirzâ & Zübeyde Hanım \\
\hline & Faruk Ferruh Seyyar (Seyr) Mirzâ & Cevri Ruveyde Hanım \\
\hline & Tayfur Mirzâ & \\
\hline
\end{tabular}

9 Rebiülahır 1163/18 Mart 1750 tarihli Limni Naibi ve Cizyedârına gönderilen mâlî hükümde ise, bundan böyle yirmi beş nefer etba'1yla Limni'de ikamet edecek olan Sam Mirzâ'ya 5 guruş 50 akçe yevmiye tayin edildiği ve bu meblağın Limni cizyesinden ödeneceği bildirilmiş, ayrıca adı geçen şehzâdeye zaruret ve sıkıntı çektirilmemesi hususunda tenbihatta bulunulmuştur ${ }^{13}$. Sam Mirzâ'nın maiyetinin kaç kişi olduğu konusunda aynı tarihleri ihtiva eden belgelerde böyle karışıklıkların olması düşündürücüdür. Fakat her halükârda bu sayı on kişiden fazla olsa gerektir ya da zamanla bu sayı artmıştır diye düşünmek daha doğrudur. Aşağıdaki tabloda da görüleceği gibi maiyet halkı yirmi beş kişiyle de sınırlı kalmamıştır. Sam Mirzâ’ya maişeti için tayin olunan aylık 500 guruşun, vefatından sonra zevceleri, oğulları, kızları ve maiyet halkına taksimine dair hükümde, maiyet halkı ailesi hariç kırk dört kişi olarak gösterilmekte, böylece toplam sayı Sam Mirzâ da dahil edildiğinde elli dokuza ulaşmaktadır ${ }^{14}$.

9 Sinop Kadısı'na, Limni Naibi’ne, Sam Mirzâ'yı Limni’ye irsâle memur mübâşire, Sinop zabiti, gümrük emini ve Limni Adasında olan zâbitâna hüküm (Evahır-1 Rebiülevvel 1163/Mart 1750): BOA, Atik Şikayet Defterleri, nr. 174, s. 11.

10 Aynı defter, s. 12. Aynı mealde te'kîden Limni Naibine ve zâbitine yine aynı tarihli ayrıca emirler gönderilmiştir: ayni defter, s. 13-14.

11 BOA, C.HR, nr. 955.

12 BOA, C.HR, nr. 955.

13 BOA, $M A D$, nr. 9968, s. 134.

14 BOA, $M A D$, nr. 9995, s. 24-27. 


\begin{tabular}{|c|c|c|c|c|c|}
\hline & $\begin{array}{l}\text { Sam Mir } \\
\text { (Limni' }\end{array}$ & $\begin{array}{l}\text { Tablo } 2 \\
\text { zâ'nın Maiye } \\
\text { le Vefat Eden }\end{array}$ & & & \\
\hline Kiși & Vazife veya Alakası & Zevceleri & Oğulları & Kızları & Toplam \\
\hline Mehmed & Kethudas 1 & Zeyneb & Hasan & $\begin{array}{l}\text { Nuriye } \\
\text { Fatıma } \\
\text { Esma }\end{array}$ & 6 kişi \\
\hline Molla Ali & Emekdarlarından & Fatıma & - & $\begin{array}{l}\text { Emetullah } \\
\text { Hatice }\end{array}$ & 4 kişi \\
\hline Yakub & Emekdarlarından & Hatice & $\begin{array}{l}\text { Emin } \\
\text { Ahmet }\end{array}$ & - & 4 kişi \\
\hline El-Hac Mehmed & Emekdarlarından & - & \begin{tabular}{|l|} 
Hasan \\
Hüseyin
\end{tabular} & - & 3 kişi \\
\hline Diğer Mehmed & Emekdarlarından & İsmihan & - & Saliha & 3 kişi \\
\hline Müteveffa Abdullah Bey & Taallukatından & Ümmükülsüm & Sadullah & Meryem & 3 kişi \\
\hline Kazım Efendi & Emekdarlarından & Hatice Hatun & - & - & 2 kişi \\
\hline Müteveffa Mehmed Han & Taallukatından & Gülperi & \begin{tabular}{|l|} 
İsmail \\
Mustafa
\end{tabular} & Fatıma & 4 kişi \\
\hline Molla Ali b. Mustafa & Emekdarlarından & - & - & - & 1 kişi \\
\hline Rüstem b. Abdullah & Emekdarlarından & & & & 1 kişi \\
\hline Selim b. Abdullah & Emekdarlarından & & & & 1 kişi \\
\hline Ahmed b. Abdullah & Emekdarlarından & & & & 1 kişi \\
\hline Yusuf b. Ahmed & $\begin{array}{l}\text { Oğlu Mehmed } \\
\text { Mirza'nın hademesi }\end{array}$ & & & & 1 kişi \\
\hline Ahmed b. Mustafa & $\begin{array}{l}\text { Oğlu Ali Mirza'nın } \\
\text { hademesi }\end{array}$ & & & & 1 kişi \\
\hline Yahya b. Halil & $\begin{array}{l}\text { Oğlu Abbas Mirza'nın } \\
\text { hademesi }\end{array}$ & & & & 1 kişi \\
\hline Mehmed b. Mustafa & $\begin{array}{l}\text { Oğlu Ferruh Seyyar } \\
\text { Mirza'nın hademesi }\end{array}$ & & & & 1 kişi \\
\hline Ahmed b. Hüseyin & $\begin{array}{l}\text { Oğlu Süleyman } \\
\text { Mirza'nın hademesi }\end{array}$ & & & & 1 kişi \\
\hline Yusuf b. Ömer & $\begin{array}{l}\text { Oğlu Tayfur Mirza'nın } \\
\text { hademesi }\end{array}$ & & & & 1 kişi \\
\hline Asiye bnt. Yakub & $\begin{array}{l}\text { Kızı Hatice Hanımın } \\
\text { Hademesi }\end{array}$ & & & & 1 kişi \\
\hline Emine bnt. Abdullah & $\begin{array}{l}\text { Kızı Fatıma Hatunun } \\
\text { hademesi }\end{array}$ & & & & 1 kişi \\
\hline Fatıma bnt. Mehmed & $\begin{array}{l}\text { Kızı Zeynep Hanımın } \\
\text { hademesi }\end{array}$ & & & & 1 kişi \\
\hline Fatıma bnt. Ali & $\begin{array}{l}\text { Kızı Zübeyde Hanımın } \\
\text { hademesi }\end{array}$ & & & & 1 kişi \\
\hline Hatice bnt. Ali & $\begin{array}{l}\text { Kızı Cevri Ruveyde } \\
\text { Hanımın hademesi }\end{array}$ & & & & 1 kişi \\
\hline \multicolumn{5}{|l|}{ TOPLAM } & 44 kişi \\
\hline
\end{tabular}

15 BOA, MAD, nr. 9995, s. 24-27; C.HR, nr. 955 (4).

16 Her iki Sam Mirzâ'nın maiyet halkı ve aile efradını ayrı bir çalışmada ele alacağımızdan burada maiyet halkının listesi verilmekle iktifầ olunmuștur. 
Osmanlı hükumeti, Sinop'a geldiği andan Limni Adası'nda vefatına kadar Sam Mirzâ'nın ihtiyaçlarını karşılamaya ve ona zaruret çektirmemeye özen göstermiştir. Sam Mirzâ'ya tahsis edilen meblağ, Sinop'ta iken Sinop Gümrüğü mukataasından, Limni'de ikameti esnasında ise Limni cizyesinden verilmiştir. Yukarıda söylendiği gibi, Sam Mirzâ'nın aile ve maiyet halkının sayısı zamanla artmış ve bu artışa paralel olarak maişeti için kendisine verilen tayinât mikdarına da zam yapılmıştır. Şehzâdenin, muhtemelen maiyet halkı sayısının artması sebebiyle kendisine verilen meblağın kifayet etmediğine, geçim sıkıntısı çektiğine ve yevmiyesine zam yapılmasına dair müracaatları geri çevrilmeyerek olumlu karşılanmış, kesret-i iyâl ü evlâd ve etbâ' ile me'lûf ${ }^{17}$ olduğu göz önünde bulundurularak her defasında yevmiyesine zam yapılmış ve nihayet aylığı 500 guruşa yükseltilmiştir. Aşağıdaki tabloda Sam Mirzâ'nın tahsîsâtına muhtelif tarihlerde yapılan zamlar görülmektedir.

\begin{tabular}{|c|c|c|c|}
\hline \multicolumn{4}{|c|}{$\begin{array}{c}\text { Tablo } 3 \\
\text { Sam Mirzâ'ya Tahsîs Olunan Tayinât } \\
\text { (Limni'de Vefat Eden) }\end{array}$} \\
\hline $\begin{array}{l}\text { Tayinât } \\
\text { Mikdarı } \\
\text { (Yevmiye) } \\
\end{array}$ & $\begin{array}{l}\text { İkamet } \\
\text { Yeri }\end{array}$ & $\begin{array}{l}\text { Tayinâtın } \\
\text { Verildiği } \\
\text { Kalem } \\
\end{array}$ & Açıklama \\
\hline 5 Guruş (?) & Sinop & $\begin{array}{l}\text { Sinop Gümrük } \\
\text { Mukataası }\end{array}$ & 1159-1160/1746-1747? senesinde Sinop'a geldiği andan itibaren. \\
\hline 5 guruş 50 akçe & Limni & Limni Cizyesi & 1162/1748-1749'da Limni Adası'na geldiği andan itibaren ${ }^{18}$. \\
\hline $\begin{array}{l}\text { 7,5 guruş } 50 \\
\text { akçe }\end{array}$ & Limni & Limni Cizyesi & $\begin{array}{l}\text { Evlad, iyal ve etbâının çokluğu ve tahsîsâtının yetmediğine dair } \\
\text { müracaatı neticesinde } 1 \text { Şaban } 1164 / 25 \text { Haziran } 1751 \text { 'den geçerli } \\
\text { olmak üzere yevmiyesine } 2,5 \text { guruş zam ile }{ }^{19} \text {. }\end{array}$ \\
\hline 10 guruş & Limni & Limni Cizyesi & $\begin{array}{l}\text { Daha önce tayin edilen } 7,5 \text { guruş } 50 \text { akçenin } 25 \text { nefer maiyetine } \\
\text { kifâyet etmediğine dair müracaatı üzerine } 1 \text { Recep } 1166 / 4 \text { Mayis } \\
1753 \text { 'ten itibaren geçerli olacak şekilde yevmiyesine } 2 \text { guruş } 10 \\
\text { akçe zam ile }{ }^{20} \text {. }\end{array}$ \\
\hline 10 guruş & Limni & Limni Cizyesi & $\begin{array}{l}28 \text { Safer 1168/14 Aralık 1754'de III. Osman'in cülûsu münasebetiyle, } \\
13 \text { C 1166/17 Nisan } 1753 \text { 'te verilen fermanın tecdîdi²1. }\end{array}$ \\
\hline 12 guruş & Limni & Limni Cizyesi & $\begin{array}{l}10 \text { guruş yevmiyenin yetmediğine dair müracaatı üzerine padişahın } \\
\text { merhametini celb ettiğinden } 1 \text { Şaban } 1170 / 21 \text { Nisan } 1757 \text { 'den } \\
\text { itibaren geçerli olmak üzere yevmiyesine } 2 \text { guruş zam ile }{ }^{22} \text {. }\end{array}$ \\
\hline 12 guruş & Limni & Limni Cizyesi & $\begin{array}{l}17 \text { Safer 1171/ } 31 \text { Ekim } 1757 \text { 'de III. Mustafa'nın cülûsu } \\
\text { münasebetiyle yukarıda verilen meblağı tecdîd için tekrar hüküm } \\
\text { yazılmasıyla }^{23} \text {. }\end{array}$ \\
\hline 15 guruş & Limni & Limni Cizyesi & $\begin{array}{l}\text { Limni Kadısı Mevlana Seyyid Halil'in, Sam Mirzâ'nın tayînâtının } \\
\text { yetmediğine, çok mikdarda borca girdiğine ve hallerinin perişan } \\
\text { olduğuna dair ilâmı üzerine } 1 \text { Muharrem } 1172 / 4 \text { Eylül } 1758 \text { 'den } \\
\text { itibaren geçerli olmak üzere } 3 \text { guruş zam ile }{ }^{24} \text {. }\end{array}$ \\
\hline $\begin{array}{l}16 \text { guruş } 80 \\
\text { akçe }\end{array}$ & Limni & Limni Cizyesi & $\begin{array}{l}1 \text { Ramazan } 1178 / 22 \text { Şubat } 1765 \text { 'den itibaren geçerli olmak üzere } 1 \\
\text { guruş } 80 \text { akçe zam ile aylık } 500 \text { guruşa çıkarılmıştır }{ }^{25} \text {. }\end{array}$ \\
\hline
\end{tabular}

17 BOA, $M A D$, nr. 9970, s. 213, (28 Cemaziyelâhır 1164/28 Nisan 1751 tarihli hüküm).

18 BOA, C.HR, nr. 8541; MAD, nr. 9968, s. 134.

19 BOA, $M A D$, nr. 9970, s. 213, (28 Cemaziyelâhır 1164/28 Nisan 1751 tarihli hüküm)

20 BOA, $M A D$, nr. 9974, s. 157, (12 Cemaziyelâhır 1166/16 Nisan 1753 tarihli hüküm)

21 BOA, $M A D$, nr. 9978, s. 109, (6 Zilka'de 1168/13 Eylül 1755 tarihli hüküm)

22 BOA, $M A D$, nr. 9983, s. 115, (22 Rebiülevvel 1171/4 Aralık 1757 tarihli hüküm)

23 BOA, $M A D$, nr. 9983, s. 115, (22 Rebiülevvel 1171/4 Aralık 1757 tarihli hüküm)

24 BOA, $M A D$, nr. 9983, s. 474, (7 Zilka'de 1171/13 Temmuz 1758 tarihli hüküm).

25 BOA, C.HR, nr. 8541, (2 Ramazan 1178 /23 Şubat 1765). 
1178/Nisan-Mayıs 1765 senesinin sonlarında Sam Mirzâ'nın vefat ettiği anlaşılmaktadır. Kesin vefat tarihini gösteren bir belgeye maalesef tesadüf edemedik. Ancak 1 Ramazan 1178/22 Şubat 1765 tarihinden geçerli olmak üzere yevmiyesine bir guruş seksen akçe zam yapıldığında henüz hayattadır ve bu belge 2 Ramazan 1178/23 Şubat 1765 tarihini

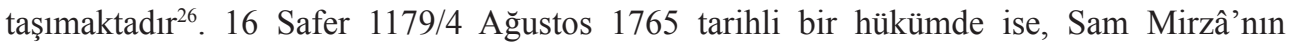
vefatından bahisle kendisine verilen aylık tayînâtının 1 Zilhicce 1178/22 Mayıs 1765'den itibaren, hanımları, çocukları ve maiyetine taksim edilmesi istenmektedir ${ }^{27}$. Şu hâlde Limni Adası'nda ikamet eden Sam Mirzâ'nın vefatı 2 Ramazan 1178/23 Şubat 1765 ile 1 Zilhicce 1178/22 Mayıs 1765 arasında vuku bulmuştur denilebilir. Vefat ettiğinde geriye elli sekiz kişiden oluşan bir maiyet bırakmıştır.

\section{Gelibolu'da Vefat Eden Sam Mirzâ}

Bu şehzâdenin ilticâsını Çıldır Valisi Ahmed Paşa'nın merkeze gönderdiği arz-1 halden²8 öğrenmekteyiz. Buna göre, Ramazan ayında yanında beş-on atlı ile Eli Perdeli Sam namında biri Tiflis'ten gelerek onun marifetiyle sığınma talebinde bulunmuştur. Arz-1 hâlin üzerindeki buyruldunun tarihi 9 Safer 1171/23 Ekim 1757 olduğuna göre şehzâdenin Çıldır'a geliş tarihi 1170 Ramazanı/Mayıs-Haziran 1757 olmalıdır. Ahmed Paşa'nın arz-1 hâline göre Sam Mirzâ, Şah Hüseyin'in oğlu Tahmasb Şah'ın oğlu olduğunu söylüyor, daha önce Osmanlı Devleti'ne sığınan ve Kars taraflarında cepheye de gönderilen Safî Mirzâ benim amcamdır diyor; Nâdir Şah zamanında firaren Rusya tarafına gittiğini, bir müddet oralarda saklandıktan sonra Tiflis'e gelerek hanların yanında kaldığını, sonunda Devlet-i Aliyye'ye halini arz ederek iltica etmek istediğini ve bu isteğini devlet merkezine bildirilmesini talep ediyor.

Ahmed Paşa, Sam Mirzâ'nın Farsça kaleme aldığı mektubuyla ${ }^{29}$ birlikte sunduğu arz-1 hâlinde, yukarıdaki hususları yazdıktan sonra bundan sonra nasıl hareket edeceğini sormuştur. Arz-1 hâlin yanına kaydedilen der-kenardan öğrendiğimize göre, Sam Mirzâ'nın yanına yeteri kadar adam koşarak Erzurum'a ulaştırması için Ahmed Paşa’ya, aynı şekilde Sinop'a ulaştırması için de Erzurum Valisi Mustafa Paşa'ya emirler gönderilmiştir. Ayrıca Sinop’ta ikameti ve geçimi için Sinop gümrüğünden kifayet mikdarı tayînât verilmesi ve zaruret çektirilmemesi için de Sinop Gümrük Emini Vekiline hükümler gönderilmiştir ${ }^{30}$.

Şehzâdenin Sinop'ta ikameti esnasında yanında kaç kişi olduğuna dair herhangi bir kayda tesadüf edilememiştir. Muhtemelen bunların sayısı Limni'de ikamet eden diğer Sam Mirzâ'nın hizmetlileri kadar olmamakla beraber aile efradı ve maiyet halkının da mevcut olduğu söylenebilir.

26 BOA, C.HR, nr. 8541, (2 Ramazan 1178/23 Şubat 1765S)

27 BOA, $M A D$, nr. 9995, s. 24-25. Ayrica bkz. BOA, C.HR, nr. 955.

28 BOA, C.HR, nr. 828.

29 Mektubun özet olarak tercümesini yapmak lütfunda bulunan Dr. Vural GENÇ’e teşekkür ederim.

30 BOA, C.HR, nr. 828. 


\begin{tabular}{|l|l|l|}
\hline \multicolumn{3}{|c|}{$\begin{array}{c}\text { Tablo 4 } \\
\text { Sam Mirzânın Aile Efrad } \\
\text { (Geliboluda Vefat Eden) }\end{array}$} \\
\hline Zevceleri & Oğulları & Kızları \\
\hline Fatıma Hatun & Süleyman Mirzâ & Şehrbânû Hanım \\
\hline Meryem Hatun & İsmail Mirzâ & Habibe Hanım \\
\hline & & Cihan Hanım \\
\hline
\end{tabular}

Yukarıdaki tabloda görüldüğü gibi Sam Mirzâ'nın Gelibolu'da vefatından sonra geriye kalan ailesi yedi kişiden oluşmaktadır. Özellikle çocuk sayısı bakımından diğer Sam Mirzâ ile kıyaslandığında sayının az olduğu görülür. Sinop’ta bulunduğu sırada aile ve maiyetinin çok da az olmadığı anlaşılır. Sinop mahkemesine müracaat ederek, evlad u ryâlin kesreti münasebetiyle gümrükten ödenen günlük altı guruşun yetmediğini ve büyük sıkıntı çektiğini söylemiş, yevmiyesine bir mikdar zam yapılması için tavassut etmesi hususunda Sinop Kadısı'ndan ricada bulunmuştur. Maiyetinde olanlarla alakalı bilgiler Gelibolu'da vefatı münasebetiyle kayıtlarda zikredilir. Bunların sayısı diğer Sam Mirzâ'nın yanındakilere nisbetle daha azdır. Vefatından sonra, Gelibolu cizyesinden tahsis edilen aylık beş yüz guruş ailesi ve maiyeti arasında taksim edilmiştir. Ailesi hariç maiyet halkının sayısı 16 kişidir.

\begin{tabular}{|c|c|c|c|c|c|}
\hline \multicolumn{6}{|c|}{$\begin{array}{c}\text { Tablo 5 } \\
\begin{array}{c}\text { Sam Mirzâ'nın Maiyeti } \\
\text { (Gelibolu'da Vefat Eden) }\end{array}\end{array}$} \\
\hline Kiși & Vazife veya Alakası & Zevceleri & Oğulları & Kızları & Toplam \\
\hline Yakub Ağa & Kethüdası & & & & 1 kişi \\
\hline Ali Kâşif & Divan Katibi & & & & 1 kişi \\
\hline Büyük Ahmed & Etbaindan & Fatıma & \begin{tabular}{|l|} 
Mehmed \\
Abdurrahman
\end{tabular} & \begin{tabular}{|l|} 
Hatice \\
Emetullah
\end{tabular} & 6 kişi \\
\hline Küçük Ahmed & Etbaindan & & & & 1 kişi \\
\hline Büyük Mehmed & Hazinedârı & & & & 1 kişi \\
\hline Küçük Mehmed & Etbaindan & & & & 1 kişi \\
\hline Mehmed & Kahvecisi & & & & 1 kişi \\
\hline Rüstem & Etbaindan & & & & 1 kişi \\
\hline Hüseyin & Etbaindan & & & & 1 kişi \\
\hline Azize Hanım & Büyük Ahmed'in Etbaindan & & & & 1 kişi \\
\hline Emine Hatun & Etbaindan & & & & 1 kişi \\
\hline \multicolumn{5}{|l|}{ TOPLAM } & 16 kişi \\
\hline
\end{tabular}

Muhtemelen gerek Limni’de gerekse Gelibolu'da vefat eden her iki Sam Mirzâ'nın maiyet halkının sayısı Osmanlı Devleti’ne ilk sığındıkları andan itibaren yukarıdaki tablolarda verilen kadar değildir. Zamanla artmış olmaları daha makul gibi gözükmektedir. Ayrıca her

31 BOA, C.HR, nr. 189; C.HR, nr. 6005.

32 BOA, C.HR, nr. 208; C.HR, nr. 8896; C.HR, nr. 9084. 
iki şehzâdenin bu kadar kalabalık maiyet halkıyla beraber firar etmeleri ve türlü yerlerde saklanmaları da oldukça müşkildir. Şu hâlde her ikisinin de Osmanlı Devleti'ne sığınması ve ikametlerinin istikrar bulmasından sonra maiyet halkı sayılarının tedrîcen artmış olması daha şayan-1 kabuldür diyebiliriz. Diğer taraftan, bu maiyet halkının İran menşeli kişilerden oluşup oluşmadığına dair bir kayıt da yoktur. Her iki şehzâdenin maiyet halkının isimleri incelendiğinde, dikkat çekici Fars kökenli isimler olmadığ görülecektir.

Sam Mirzâ'nın Sinop'taki ikameti 1177 yılı sonu/Mayıs 1764'e kadar sürmüş, 1178 yılı baş1/ Temmuz-Ağustos 1764'te ise Rodos'a geçmiştir. Gerek ilk gelen Safî Mirzâ gerekse her iki Sam Mirzâ'nın ilk ikamet mekânları hep Sinop Kalesi olmuş ve daha sonra her üçü de Ege Adaları'ndan birine nakledilmişlerdir. Belgelerden anlaşıldığına göre, her üçünün de Sinop ahalisi ile aralarında anlaşmazlıklar çıkması adalara nakledilmelerine sebep olmuştur. Muhtemelen bir diğer ve belki de en önemli sebep, bunların hareketlerini ve yanlarına gelip gidenleri sıkı bir şekilde kontrol altında tutmak maksadına matuf olsa gerektir. Nitekim, idarecilere gönderilen hükümlerde, adı geçen şehzâdelerin rahatlarına ihtimam etmeleri ve zaruret çektirmemeleri söylenirken, devlet merkezinden izinsiz, bulundukları yerlerden bir adım dahi dışarıya çıkmalarına müsaade olunmaması hususunda sıkı sıkıya tenbîhâtta bulunulmaktadır.

Sam Mirzâ'nın Rodos Adası'ndaki ikameti gayet kısa sürmüştür. Ada ikliminin kendisine yaramadığını ve hummâ hastalığına yakalandığını, Sinop'ta kalan ıyal ve etbaının buraya nakillerinde de zorluk bulunduğunu ifade ederek, bu sebeple Tekfurdağı, Gelibolu veya eskiden olduğu gibi tekrar Sinop'ta ikametine izin verilmesine dair sunduğu arzı üzerine Gelibolu'da karar kılınmıştır ${ }^{33}$. Buradaki ifadeden Sam Mirza'nın Rodos Adası'na yalnız nakledildiği, ailesinin ve maiyetinin daha sonra gönderilmek üzere geride birakıldı̆̆ anlaşılmaktadır. Böyle acele edilmesinde muhtemelen Sinop ahalisinin şikâyetleri ve bir an önce sükûneti temin etmek endişesi etkili olsa gerektir. Rodos cizyesinden verilen tayînâtın, 1179 Muharremi sonu/Temmuz 1765 'te buradan kesilerek 1 Safer 1179/20 Temmuz 1765'den itibaren Gelibolu cizyesinden verilmesine dair fermandan istidlâlen, şehzâdenin Gelibolu'ya geçişi 1179 Saferi/1765 Temmuz'u olmalıdır diyebiliriz ${ }^{34}$. Şu hâlde Sam Mirzâ'nın Rodos’ta kalma süresi ancak bir y1l sürmüştür.

Diğer şehzâdelerde olduğu gibi, Sinop, Rodos ve Gelibolu'da Sam Mirzâ'nın kendisine verilen tayînâtın yetmediğine ve aylığına zam yapılmasına dair müracaatları geri çevrilmemiş, aralıklarla tahsîsâtına zamlar yapılmıştır. Bazen aile efradının ve maiyetinin çokluğunu ileri sürmüş, Rodos'taki kısa ikameti esnasında buranın sengistân olduğunu ve ihtiyaçlarını karşılamakta sair yerlere kıyasen zorluk çektiğini söylemiş, bazen de kendisinden önce Rodos'ta vefat eden amcası Safî Mirzâ'yı ve Limni'deki diğer Sam Mirzâ'yı emsal göstererek kendisine de onlara verilen mikdarda tayînât verilmesini istemiştir. Osmanlı idaresi, bahane

33 BOA, $M A D$, nr. 9995 , s. 10.

34 Ayni yer. 
her ne olursa olsun, şehzâdelerin maişet konusunda gönüllerini hoş tutmaya çalışmıştır. Aşağıdaki tabloda Sinop'ta başlayıp Gelibolu'da vefatıyla noktalanan ikameti sırasında Sam Mirzâ'ya verilen tayînât görülmektedir.

\begin{tabular}{|c|c|c|c|}
\hline \multicolumn{4}{|c|}{$\begin{array}{c}\text { Tablo } 6 \\
\text { Sam Mirzâ'ya Tahsîs Olunan Tayinât } \\
\text { (Gelibolu'da Vefat Eden) }\end{array}$} \\
\hline $\begin{array}{l}\text { Tayinât } \\
\text { Mikdarı }\end{array}$ & $\begin{array}{l}\text { İkamet } \\
\text { Yeri }\end{array}$ & $\begin{array}{l}\text { Tayinâtın Verildiği } \\
\text { Kalem }\end{array}$ & Açıklama \\
\hline 3 guruş & Sinop & $\begin{array}{l}\text { Sinop Gümrüğ̈̈ } \\
\text { mukataası }\end{array}$ & $\begin{array}{l}\text { Sinop'a geldiği andan itibaren. (1171 Saferi/Ekim-Kasım } \\
1757 \text { sonrası) (9 Safer 1171/23 Ekim } 1757 \text { tarihli emir) }{ }^{35} \text {. }\end{array}$ \\
\hline 5 guruş & Sinop & $\begin{array}{l}\text { Sinop Gümrüğü } \\
\text { mukataası }\end{array}$ & $\begin{array}{l}1 \text { Şa‘ban 1171/10Nisan } 1758 \text { 'den itibaren geçerli olacak } \\
\text { şekilde } 2 \text { guruş zam ile (10 Şa‘ban 1171/19 Nisan } 1758 \\
\text { tarihli emir) }\end{array}$ \\
\hline 6 guruş & Sinop & $\begin{array}{l}\text { Sinop Gümrüğü } \\
\text { mukataası }\end{array}$ & $\begin{array}{l}1 \text { Cemaziyelevvel 1174/9 Aralık 1760'taitibaren geçerli } \\
\text { olacak şekilde } 1 \text { guruş zam ile (7 Cemaziyelevvel 1174/15 } \\
\text { Aralık } 1760 \text { tarihli emir) }{ }^{37} \text {. }\end{array}$ \\
\hline 10 guruş & Sinop & $\begin{array}{l}\text { Sinop Gümrüğü } \\
\text { mukataası }\end{array}$ & $\begin{array}{l}\text { Evlad ve etbaının kesretinden } 6 \text { guruş yevmiye ile } \\
\text { geçinemediğine dair Sinop Kadısı'nın ilâmı üzerine } 1 \\
\text { Rebiülevvel 1176/20 Eylül } 1762 \text { tarihinden geçerli olacak } \\
\text { şekilde yevmiyesine } 4 \text { guruş zam ile (18 Safer 1176/8 Eylül } \\
1762 \text { tarihli emir) }\end{array}$ \\
\hline 10 guruş & Rodos & Rodos cizyesi & $\begin{array}{l}1 \text { Safer 1178/31 Temmuz } 1764 \text { tarihinden itibaren Sinop } \\
\text { Gümrüğ̈̈̈’nden ayrilıp Rodos cizyesine bağlanmıştır (15 } \\
\text { Muharrem 1178/15 Temmuz } 1765 \text { tarihli emir) }{ }^{39} \text {. }\end{array}$ \\
\hline $\begin{array}{l}16 \text { guruş } 80 \\
\text { akçe }\end{array}$ & Rodos & Rodos cizyesi & $\begin{array}{l}1 \text { Ramazan } 1178 / 22 \text { Şubat } 1765 \text { 'den geçerli olmak üzere } \\
10 \text { guruş olan yevmiyesine, daha önce Rodos'da vefat } \\
\text { eden amcası Şah Safî ve Limni'deki diğer Sam Mirza'nın } \\
\text { yevmiyeleri emsal alınarak } 6 \text { guruş } 80 \text { akçe zam yapılmış; } \\
\text { böylece aylık tayînâtı } 500 \text { guruşa çıkarılmışıtır (2 Ramazan } \\
1178 / 23 \text { Şubat } 1765 \text { tarihli buyruldu) }{ }^{40} \text {. }\end{array}$ \\
\hline $\begin{array}{l}16 \text { guruş } 80 \\
\text { akçe }\end{array}$ & Gelibolu & Gelibolu cizyesi & $\begin{array}{l}1179 \text { Muharrem/Haziran-Temmuz } 1765 \text { tarihinde } \\
\text { Gelibolu'ya geçmesiyle 1 S 1179/20 Temmuz 1765'den } \\
\text { itibaren tayînât Gelibolu cizyesine bağlanmıştır (Evahır-1 } \\
\text { Muharrem 1179/Temmuz } 1765 \text { tarihli hüküm) }{ }^{41} \text {. }\end{array}$ \\
\hline
\end{tabular}

Sam Mirzâ, Cemaziyelahir 1183/Ekim 1769'da vefat edinceye ${ }^{42}$ kadar Gelibolu'da yaşamıştır. Kabri de buradadır. Vefatından sonra geriye yedi kişiden oluşan aile efradı ve on altı kişiden mürekkeb maiyet halkı bırakmıştır. Kendisine tayin olunan aylık beş yüz guruş tahsîsâtı da ailesi ve maiyeti arasında taksim olunmuştur ${ }^{43}$.

35 BOA, C.HR, nr. 828 .

36 BOA, C.HR, nr. 8541; C.HR, nr. 657.

37 Aynı yer.

38 BOA, C.HR, nr. 7313; C.HR, nr. 8541.

39 BOA, C.HR, nr. 8541.

40 Ayni yer.

41 BOA, $M A D$, nr. 9995, s. 10.

42 BOA, AE.III.AHMED, nr. 421.

43 BOA, C.HR, nr. 9084; C.HR, nr. 6005. 


\section{Sonuç}

Osmanlı Devleti'nin, neredeyse üç asırdır hasmı olan bir hanedanın mensuplarını hiç tereddüdsüz kabul ve himaye etmesi üzerinde çokça düşünülmesi gereken bir husustur denilse yanlış olmaz. Hiçbir devlet başka bir devletin önde gelen önemli bir şahsını hiçbir menfaat gözetmeksizin topraklarında barındırıp onları beslemez. Gerçekten Osmanlı Devleti de kendisine sığınan bu Safevî şehzâdelerinden başlangıçta siyasî olarak istifade etmek istemiş, hatta bunların ilki olan Safî Mirzâ'yı şah ilan ederek İran tahtına oturtmayı hedeflemiş, bunun için adı geçen şehzâdeyi harb halinde olduğu İran hududuna kadar da göndermiş; ancak beklediği neticeyi elde edememiştir. Sonra gelen her iki Sam mirzâlar için böyle bir durum da söz konusu değildir. Onlar doğrudan belli yerlerde iskân edilerek hem kendilerinin hem ailelerinin hem de maiyet halkının her türlü ihtiyaçları karşılanmaya ve zaruret çektirilmemeye özen gösterilmiştir. Bir müddet sonra, bu şehzâdelerden siyasî istifade yolu tamamen kapanmıştır. Hatta şehzâdelerin vefatlarından sonra, çocukları ve torunlarını neredeyse Osmanlı Devleti'nin sonuna kadar maaşlar tahsis olunarak himayeye devam edilmiştir. Siyasî istifade yolu kapandığı, varlıkları devlet hazinesine yük olduğu ve üstelik bazı sosyal sıkıntıları da beraberinde getirdiği halde bu himayenin devamının sebebi neydi? Aslında buna yön veren prensipler, resmî ve özel Osmanlı belgelerinde ifâde edilmektedir. Bir mühimme hükmünde, Safî Mirzâ'nın kabul ve himâye edilmesinin sebebi, dostluk ve sevgiyi bina etmek ve muhabbet ve vefayı güçlendirmek (bünyân-ı mirh ü vilâ ve erkân-ı hubb u vefânın istihkâmı), Osmanlı Padişâhının bu davranışı ise şahlara yaraşır bir yiğitlik ve padişahlığa uygun şefkat ve merhamet (muvâfik-ı şîme-i mürüvvet-i şâhâne ve mutâbık-ı deydene-i atûfet-i pâdişâne) olarak ifâde ediliyor ${ }^{44}$. Safî Mirzâ'nın şahlık berâtında ise âyîn-i düvel-i izâm ve kavânîn-i mülûk-i İslâm ibâresiyle bu durum, büyük devlet olmanın özelliği ve İslâm hükümdarlarının kanunu olarak gösterilmektedir ${ }^{45}$. Yukarıda sayılan prensiplerin ecdâddan mütevâris olduğu vurgusuyla da himaye, dostluk, yardım, vefa gibi hasletlerin âna mahsus olmayıp Osmanlı Devleti'nde eskiden beri devam edegelen bir gelenek olduğu ifade edilmektedir. Nitekim Şemdânî-zâde, devlete ilticâ edenleri reddetmeyip ikrâm etmenin $k \bar{a}$ 'ide-i devletden olduğunu söylerken ${ }^{46}$ Subhî Mehmed Efendi de bu davranışın sebebini âdet-i hasene-i şehr-yârî ve kā ide-i müstahsene-i cihân-dârî diye tarif etmektedir ${ }^{47}$.

Bir başka husus, Osmanlı Devleti bir hanedân devletidir ve her ne kadar hasım dahi olsalar, gadre uğrayan düşman hanedân mensuplarını korumak ve himaye etmek bir nevi gelenek gibi görülebilir, hanedân dayanışması şeklinde değerlendirilebilir. Nitekim bunun misalleri batıdan iltica edenlerde de görülmektedir.

44 BOA, Mühimme, nr. 150, s. 105/387.

45 BOA, C.HR, nr. 4469.

46 Mür'i't-tevârîh, haz. M. Münir Aktepe, c. I, İstanbul 1976, s. 132.

47 Subhî Târihî, Sâmî ve Şâkir Tarihleri ile Birlikte (İnceleme ve Karşılaştırmalı Metin), haz. Mesut Aydıner, İstanbul 200, s. 791. 
$\mathrm{Bu}$ üç şehzâdenin ailelerinin ve maiyet halkının, 18 ve 19. asırlar boyunca Osmanlı topraklarındaki vaziyetleri ayrıca üzerinde çalışılması gereken bir durumdur. Acaba bu şehzâdelerin ahfâdı, Şia itikadını sonuna kadar muhafaza etmişler midir? Yoksa Sünnî mezhebine geçişler olmuş mudur? Diğer taraftan, hayatın değişmez kanunu olan evlenme ve yuva kurma konusundaki vaziyetleri nedir? Devletin sonuna kadar bu topraklarda yaşadıklarına göre evliliklerini nasıl gerçekleştirmişlerdir? Tercihlerinde mezheb mensubiyetleri belirleyici olmuş mudur? Halen ülkemizde, bu üç şehzâdenin soyundan gelen kimse var mıdır? Bütün bunlar cevap bekleyen sorulardır.

Son söz olarak, yakın zamanda yaşanan hadiselerin de gösterdiği gibi, darda kalana yardım etmek ve sığınana kucak açmanın Türk milletinin değişmez hasletlerinden olduğunu, tarih boyunca bunun sayısız misalleri görüldüğünü, İran Safevî şehzâdelerinin de bu çerçevede değerlendirilmesi gerektiğini söyleyebiliriz.

Hakem Değerlendirmesi: Dış bağımsız.

Çıkar Çatışması: Yazar çıkar çatışması bildirmemiştir.

Finansal Destek: Yazar bu çalışma için finansal destek almadığını beyan etmiştir.

Peer-review: Externally peer-reviewed.

Conflict of Interest: The author has no conflict of interest to declare.

Grant Support: The author declared that this study has received no financial support.

\section{Kaynakça/References}

\section{Arşiv Kaynakları}

Türkiye Cumhuriyeti Cumhurbaşkanlığı Devlet Arşivleri Başkanlığı Osmanlı Arşivi (BOA)

Mühimme Defterleri, nr. 150, 153, 154.

Maliyeden Müdevver Defterler (MAD), nr. 9968, 9970, 9974, 9978, 9983, 9995.

Atik Şikâyet Defterleri, nr. 174.

Ali Emirî-III. Ahmed (AE.III.AHMED).

Cevdet-Hariciye (C.HR.).

\section{Diğer Mehazlar}

Aktepe, M. Münir, “Mahmud I”, İA, c. VII, İstanbul 1988, s. 158-165.

Garthwaite, Gene R., Iran Tarihi, Pers Imparatorluğu’ndan Günümüze, çev. Fethi Aytuna, İstanbul 2011.

Ginio, Eyal, “Beyaz Kule Şehrinde Bir Safevî Prensi: Selanik’teki Beyzâde (1731-1734)”, çev. Özgür ÇınarlıÇağdaş Firat, Türkler, c. XII, Ankara 2001, s. 576-581.

Güler, İbrahim, “XVIII. Yüzyılda Sinop'ta İran Şehzâdeleri”, Prof. Dr. Hakkı Dursun Yıldız Armağanı, İstanbul 1995, s. 259-266. 
Gündüz, Tufan, “Safevîler”, DİA, c. XXXV, İstanbul 2008, s. 451-457.

İşbilir, Ömer, “Osmanlı Ülkesi’nde Bir Safevî Şehzâdesi: Safî Mirzâ”, Tarihin Peşinde Bir Ömür -Abdülkadir Özcan'a Armağan, ed. Hayrunnisa Alan vd., İstanbul 2018, s. 543-560.

Minorsky, V., "Nadir", $\dot{I} A$, c. IX, İstanbul 1988, s. 21-31.

Özcan, Azmi, "Nadir Şah”, DİA, c. XXXII, İstanbul 2006, s. 276-277.

Sanvory, R. M., “Safevî İran'1”, İslam Tarihi Kültürü ve Medeniyeti, c. I, çev. Mehmet Maksudoğlu, İstanbul 1988, s. 426-427.

Subhî Mehmed Efendi, Subhî Târihî, Sâmî ve Şâkir Tarihleri ile Birlikte (İnceleme ve Karşılaştırmalı Metin), haz. Mesut Aydıner, İstanbul 2007.

Şem‘dânî-zâde Fındıklılı Süleyman Efendi, Mür'i ’t-tevârîh, haz. M. Münir Aktepe, c. I, İstanbul 1976.

Taşağıl, Ahmet, "Hüseyin Mirza”, DİA, c. XIX, İstanbul 1999, s. 1-2. 


\section{EKLER}

Ek 1

Tahmasb Oğlu Sam Mirzâ'nın Farsça Mektûbunun Tercümesi (BOA, C.HR, nr. 828).

$\mathrm{Bu}$ duacı kulun arzı, dergâh-1 âli'nin bendesinin maruzâtı şudur ki, Müslümanların âlem-penah sultanının devletinin duacısı olan bu kul, ebedi saltanatın eşiğinin bu bendesi şüpheye yer yok ki, Şah Hüseyin'in oğlu Şah Tahmasb'ın oğludur. Yaratıcının sonsuz olan takdiri gereğince çocukluk çağındayken Nadir Şah'ın bize yaptığı cevr ve zulüm yüzünden babamın yardımıyla firar edip Gilan, Azerbaycan, Ahıska taraflarına geldik. Bir müddet sonra Efrence-i Benî Asfer vilayetlerine geldik. Biraz sonra da Tiflis'e geldik. Devlet-i aliyye'nin merhamet eteklerine el sürmek ümidiyle bir müddet sonra düşe kalka kaçar halde gelerek Ahmed Paşa'nın vilayeti olan Çıldır'a kavuştuk. Bizi çok iyi karşıladı. Bu zulüm görmüş kulun maruzatı şudur ki eğer Allah'ın yardımıyla Devlet-i Aliyye-i Hüsrevâne'nin merhamet denizi dalgalanacak olursa ve reva görürlerse dergâh-1 âlem-penahın eşiğinin mülâzımlarından olayım. Umarım ki, Hüdâvendigar-1 gerdûn-iktidarın inayet gözünün bir kırpmasıyla bu kulun muradı hasıl olur.

Duacı kulunuz

Sam b. Şah Tahmasb b. Şah Hüseyin 


\section{Ek 2}

\section{Çıldır Valisi Vezir Ahmed Paşa'nın Tahmasb Oğlu Sam Mirzâ'nın İlticâsına Dair Arzı} (BOA, C.HR, nr. 828)

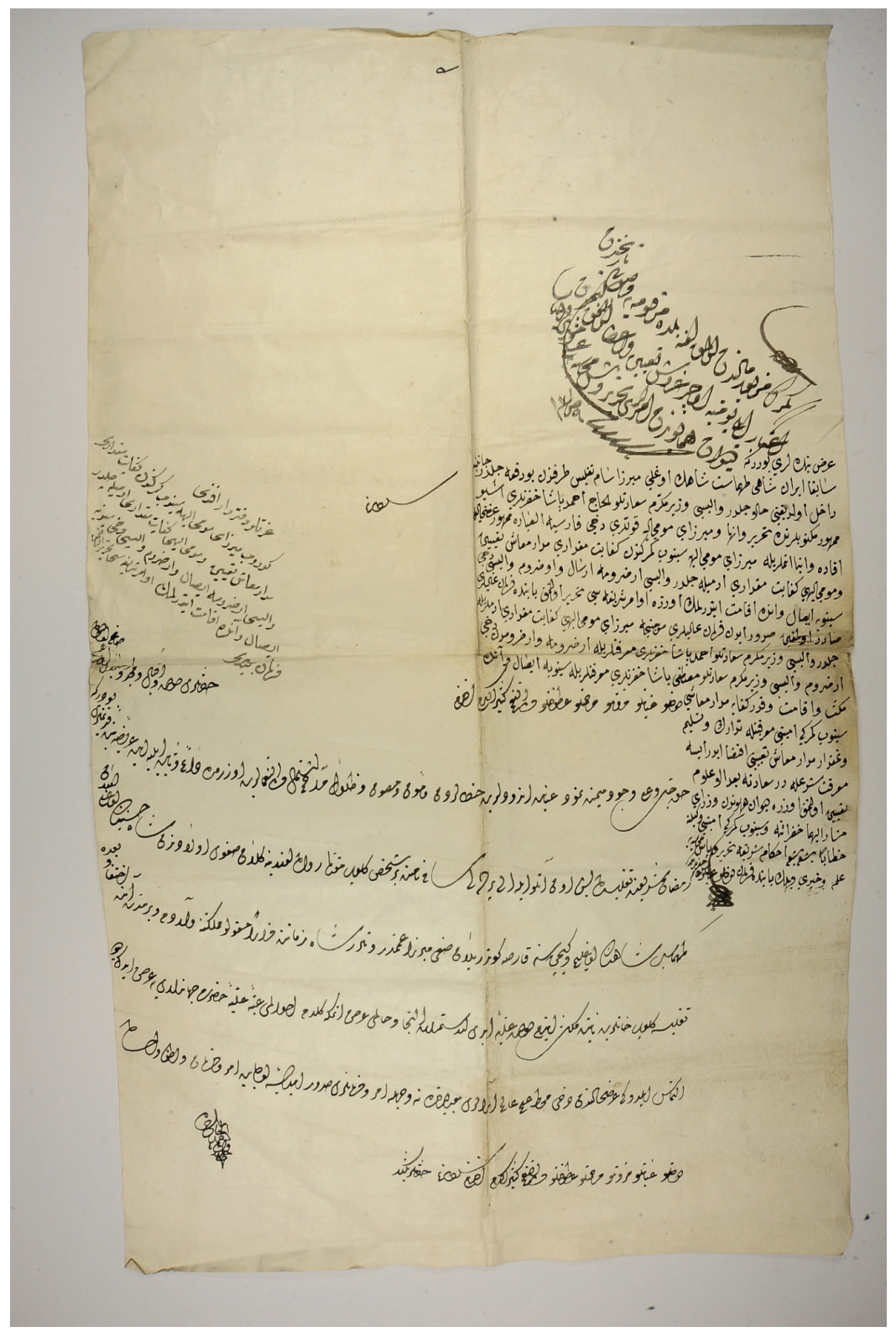

